Article

\title{
Genetic Analyses in Dent Disease and Characterization of CLCN5 Mutations in Kidney Biopsies
}

\author{
Lisa Gianesello ${ }^{1,+}\left(\mathbb{D}\right.$, Monica Ceol ${ }^{1, \dagger}$, Loris Bertoldi ${ }^{2,+}{ }^{\oplus}$, Liliana Terrin ${ }^{1}$, Giovanna Priante ${ }^{1}(\mathbb{D}$, \\ Luisa Murer $^{3}$, Licia Peruzzi ${ }^{4}\left(\mathbb{D}\right.$, Mario Giordano $^{5}\left(\mathbb{D}\right.$, Fabio Paglialonga ${ }^{6}$, Vincenzo Cantaluppi ${ }^{7}$, \\ Claudio Musetti ${ }^{7}$, Giorgio Valle ${ }^{2}$, Dorella Del Prete ${ }^{1}$, Franca Anglani ${ }^{1,2, *(\mathbb{D})}$ and Dent Disease \\ Italian Network $\ddagger$ \\ 1 Laboratory of Histomorphology and Molecular Biology of the Kidney, Clinical Nephrology, \\ Department of Medicine-DIMED, University of Padua, 35128 Padua, Italy; lisa.gianesello@unipd.it (L.G.); \\ monica.ceol@unipd.it (M.C.); liliana.terrin@gmail.com (L.T.); giovanna.priante@unipd.it (G.P.); \\ dorella.delprete@unipd.it (D.D.P.) \\ 2 CRIBI Biotechnology Centre, University of Padua, 35131 Padua, Italy; loris.bertoldi@phd.unipd.it (L.B.); \\ giorgio.valle@unipd.it (G.V.) \\ 3 Pediatric Nephrology, Dialysis and Transplant Unit, Department of Women's and Children's Health, \\ Padua University Hospital, 35128 Padua, Italy; luisa.murer@aopd.veneto.it \\ 4 Pediatric Nephrology Unit, Regina Margherita Children's Hospital, 10126 CDSS Turin, Italy; \\ licia.peruzzi@unito.it \\ 5 Pediatric Nephrology Unit, University Hospital, P.O. Giovanni XXIII, 70126 Bari, Italy; \\ mario.giordano@policlinico.ba.it \\ 6 Pediatric Nephrology, Dialysis and Transplant Unit, Fondazione IRCCS, Ca' Granda Ospedale Maggiore \\ Policlinico, 20122 Milan, Italy; fabio.paglialonga@policlinico.mi.it \\ 7 Nephrology and Kidney Transplantation Unit, Department of Translational Medicine, University of \\ Piemonte Orientale (UPO), 28100 Novara, Italy; vincenzo.cantaluppi@med.uniupo.it (V.C.); \\ claudio.musetti@med.uniupo.it (C.M.) \\ * Correspondence: franca.anglani@unipd.it; Tel.: +39-049-8212-155 \\ + These authors contributed equally to this work. \\ $\ddagger$ Membership of the Dent Disease Italian Network is provided in the Acknowledgments.
}

Received: 4 December 2019; Accepted: 10 January 2020; Published: 14 January 2020

\begin{abstract}
Dent disease (DD), an X-linked renal tubulopathy, is mainly caused by loss-of-function mutations in CLCN5 (DD1) and OCRL genes. CLCN5 encodes the ClC-5 antiporter that in proximal tubules (PT) participates in the receptor-mediated endocytosis of low molecular weight proteins. Few studies have analyzed the PT expression of ClC-5 and of megalin and cubilin receptors in DD1 kidney biopsies. About $25 \%$ of DD cases lack mutations in either CLCN5 or OCRL genes (DD3), and no other disease genes have been discovered so far. Sanger sequencing was used for CLCN5 gene analysis in 158 unrelated males clinically suspected of having DD. The tubular expression of ClC-5, megalin, and cubilin was assessed by immunolabeling in 10 DD1 kidney biopsies. Whole exome sequencing (WES) was performed in eight DD3 patients. Twenty-three novel CLCN5 mutations were identified. $\mathrm{ClC}-5$, megalin, and cubilin were significantly lower in DD1 than in control biopsies. The tubular expression of ClC-5 when detected was irrespective of the type of mutation. In four DD3 patients, WES revealed 12 potentially pathogenic variants in three novel genes (SLC17A1, SLC9A3, and PDZK1), and in three genes known to be associated with monogenic forms of renal proximal tubulopathies (SLC3A, LRP2, and CUBN). The supposed third Dent disease-causing gene was not discovered.
\end{abstract}

Keywords: dent disease; CLCN5 gene mutations; proximal tubular ClC-5 expression; megalin; cubilin; kidney biopsies; immunohistochemistry; whole exome sequencing 


\section{Introduction}

The term Dent disease (DD) identifies a group of X-linked renal disorders characterized by features of incomplete Fanconi syndrome including low-molecular-weight proteinuria (LMWP), and more or less severe hypercalciuria, nephrocalcinosis and/or nephrolithiasis. This triad of symptoms has been variously named in the past as X-linked recessive nephrolithiasis with renal failure (OMIM 310468), X-linked recessive hypophosphatemic rickets (OMIM 300554), or the idiopathic LMWP of Japanese children (OMIM 308990), testifying to the disease's phenotypic variability [1,2]. DD usually presents in children or young adults, progressing to chronic kidney disease (CKD) between the third and fifth decades of life in $30-80 \%$ of cases [3,4].

The most common genetic cause of DD is a mutated CLCN5 gene encoding the ClC-5 chloride channel Cl-/H+ antiporter (DD1; MIM\#300009) [5-9]. In the kidney, ClC-5 is expressed primarily in the proximal tubular cells (PTCs) located mainly in the subapical endosomes. Together with megalin and cubilin synergistic receptors, it is involved in the endocytic reabsorption of albumin and LMW proteins $[10,11]$. ClC-5 expression levels are lower in the $\alpha$ intercalated cells of the cortical collecting duct and in the cortical and medullary thick ascending limb of Henle's loop [12].

DD1 features a marked allelic heterogeneity, with more than 200 CLCN5 mutations described so far [9]. Functional investigations in Xenopus Levis oocytes and mammalian cells enabled these CLCN5 mutations to be classified. The most common mutations lead to a defective protein folding and processing, resulting in endoplasmic reticulum (ER) retention of the mutant protein for further degradation by the proteasome [13-17]. Few studies have investigated ClC-5 expression in DD1 kidney biopsies.

OCRL gene mutations, which are usually associated with Lowe syndrome (OMIM \#309000), have been identified in about $10-15 \%$ of DD patients (DD2; MIM\#300555). Approximately $25 \%$ of DD patients (DD3) have neither CLCN5 nor OCRL gene mutations [18-21].

This study aimed to investigate allelic and locus heterogeneity in DD and to analyze ClC-5, megalin, and cubilin expression in DD1 kidney biopsies. We further expanded the spectrum of CLCN5 mutations in DD by describing 23 novel mutations. In DD1 kidney biopsies, we showed that the loss of ClC-5 tubular expression caused defective megalin and cubilin trafficking. In DD3, whole exome sequencing (WES) did not detect a new disease-causing gene. Instead, it revealed the concomitant presence of likely pathogenic variants in genes encoding proximal tubular (PT) endocytic apparatus components, suggesting that they may have had a role in determining the DD3 phenotype.

\section{Results}

\subsection{CLCN5 Gene Mutation Analysis}

The $85 \%$ of the 158 patients analyzed for the presence of CLCN5 mutations were of Italian origin, $6 \%$ were non-Italian European (Balcanic and English), and the remaining 9\% were extra-European (Figure 1).

DNA sequence analysis of the CLCN5 gene revealed 50 different mutations in 56 unrelated patients. Six different mutations were found twice. Among the detected mutations, the most common types were missense mutations (21 cases), followed by frameshift mutations (14 cases), nonsense mutations (13 cases), and splicing mutations (eight cases) (Figure 2).

Twenty-three mutations were not previously described, which were judged potentially pathogenic by in silico tools and classified as pathogenic or likely pathogenic according to American College of Medical Genetics and American College of Pathologists (ACMG/AMP) guidelines [22] (Table 1). The novel frameshift, nonsense, and missense mutations were mapped onto $\mathrm{ClC}-5$ protein domains (Table 1). Table S1 summarizes the clinical details of 20 patients with novel CLCN5 mutations (clinical data were unavailable for three). LMWP and hypercalciuria were the most common signs at the time of their molecular diagnosis, and their clinical phenotypic variability reflected that of patients with known CLCN5 mutations [9]. 


\section{Population}

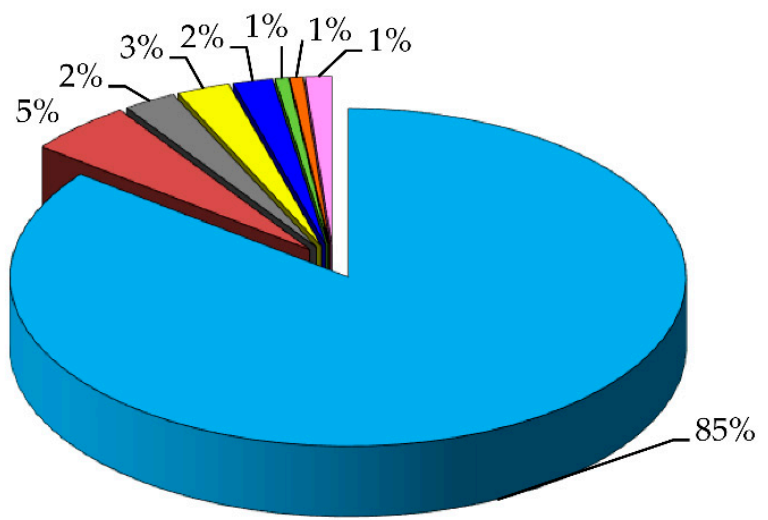

$\square$ Italian

Balcanic

$\square$ Latin-American

$\square$ Indian

Arabic

$\square$ Chinese

$\square$ African

$\square$ English

Figure 1. Ethnical distribution of the 158 analyzed patients.

\section{CLCN5 mutations}

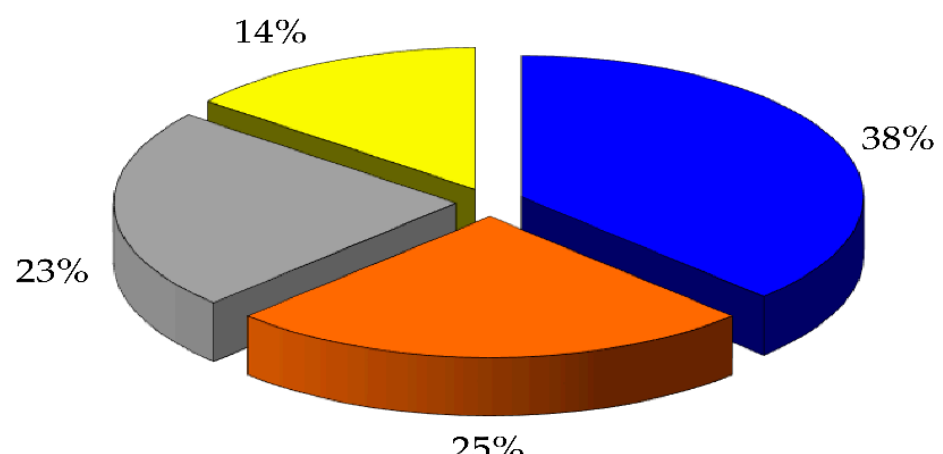

missense $\square$ frameshift $\square$ nonsense $\square$ splicing

Figure 2. Percentages of mutations of CLCN5 gene by type.

Table 1. Novel mutations in the CLCN5 gene.

\begin{tabular}{|c|c|c|c|c|c|}
\hline $\begin{array}{c}\text { Type of } \\
\text { Mutation }\end{array}$ & Nucleotide & Exon-Intron & Protein & $\begin{array}{c}\text { Pathogenicity } \\
\text { Assessment }\end{array}$ & Protein Domain \\
\hline Frameshift & c.100_101insG & Exon 2 & p.(Glu35fs) & Pathogenic (Ib) & A helix, stop in Loop A-B \\
\hline Frameshift & c.125delA & Exon 3 & p.(Glu42fs) & Pathogenic $(\mathrm{Ib})$ & Loop A-B \\
\hline Frameshift & c.266_267insT & Exon 4 & p.(Ile89fs) & Pathogenic $(\mathrm{Ib})$ & B helix, stop in Loop B-C \\
\hline Frameshift & c.518delT & Exon 6 & p.(Ile173fs) & Pathogenic (Ib) & D helix, stop in Loop D-E \\
\hline Frameshift $\S$ & c.691delA & Exon 6 & p.(Lys231fs) & Pathogenic (Ia) & $\begin{array}{c}\text { Loop F-G, stop at the end of } \\
\text { helix G }\end{array}$ \\
\hline Frameshift & c.1164_1165insAG & Exon 8 & p.(Lys388fs) & Pathogenic (Ib) & L helix, stop in helix $\mathrm{M}$ \\
\hline Frameshift & c.1635_1638delCAAG & Exon 10 & p.(Ser545fs) & Pathogenic $(\mathrm{Ib})$ & Q helix, stop in cytoplasmic \\
\hline Frameshift & c.1657delG & Exon 10 & p.(Arg554fs) & Pathogenic (Ib) & $\begin{array}{l}\text { Cytoplasmic, stop at the } \\
\text { beginning of CBS1 } \\
\text { cytoplasmic domain }\end{array}$ \\
\hline Frameshift & c.1920delC & Exon 10 & p.(Ile641fs) & Pathogenic (Ib) & $\begin{array}{l}\text { CBS1 cytoplasmic domain, } \\
\text { stop in cytoplasmic }\end{array}$ \\
\hline Nonsense & c. $1287 \mathrm{G}>\mathrm{A}$ & Exon 8 & p. $\left(\operatorname{Trp} 429^{*}\right)$ & Pathogenic (Ib) & M helix \\
\hline
\end{tabular}


Table 1. Cont.

\begin{tabular}{|c|c|c|c|c|c|}
\hline $\begin{array}{l}\text { Type of } \\
\text { Mutation }\end{array}$ & Nucleotide & Exon-Intron & Protein & $\begin{array}{l}\text { Pathogenicity } \\
\text { Assessment }\end{array}$ & Protein Domain \\
\hline Nonsense & c. $2016 C>G$ & Exon 11 & p.(Tyr672*) & Pathogenic (Ib) & Cytoplasmic \\
\hline Nonsense & c. $2128 \mathrm{C}>\mathrm{T}$ & Exon 11 & p. $\left(\mathrm{G} \ln 710^{*}\right)$ & Pathogenic (Ib) & $\begin{array}{l}\text { Cytoplasmic-beta strand in } \\
\text { CBS2 domain }\end{array}$ \\
\hline Missense & c. $262 \mathrm{G}>\mathrm{A}$ & Exon 4 & p.(Gly88Ser) & $\begin{array}{c}\text { Likely } \\
\text { pathogenic (IV) }\end{array}$ & B helix \\
\hline Missense & c.305G $>\mathrm{T}$ & Exon 4 & p.(Cys102Phe) & $\begin{array}{c}\text { Likely } \\
\text { pathogenic }(\mathrm{V})\end{array}$ & Loop B-C \\
\hline Missense & c. $518 \mathrm{~T}>\mathrm{A}$ & Exon 6 & p.(Ile173Lys) & $\begin{array}{c}\text { Likely } \\
\text { pathogenic }(\mathrm{V})\end{array}$ & D helix \\
\hline Missense $§$ & c. $608 \mathrm{C}>\mathrm{G}$ & Exon 6 & p.(Ser203Trp) & Pathogenic (II) & E helix \\
\hline Missense & c. $809 \mathrm{G}>\mathrm{A}$ & Exon 8 & p.(Ser270Asn) & $\begin{array}{c}\text { Likely } \\
\text { pathogenic (IV) }\end{array}$ & Loop H-I \\
\hline Missense ${ }^{\S}$ & c. $922 \mathrm{G}>\mathrm{A}$ & Exon 8 & p.(Val308Met) & $\begin{array}{l}\text { Pathogenic } \\
\text { (IIIb) }\end{array}$ & Loop I-J \\
\hline Missense & c. $1565 \mathrm{~T}>\mathrm{A}$ & Exon 10 & p.(Val522Asp) & $\begin{array}{c}\text { Likely } \\
\text { pathogenic (V) }\end{array}$ & P helix \\
\hline Missense & c. $1619 \mathrm{C}>\mathrm{T}$ & Exon 10 & p.(Ala540Val) & $\begin{array}{c}\text { Likely } \\
\text { pathogenic (IV) }\end{array}$ & Q helix \\
\hline Missense & c. $2192 \mathrm{~A}>\mathrm{C}$ & Exon 12 & p.(His731Pro) & $\begin{array}{c}\text { Likely } \\
\text { pathogenic (V) }\end{array}$ & Cytoplasmic-CBS2 domain \\
\hline Splicing & c. $105+5 G>C$ & $\begin{array}{l}\text { Intron 2-splice } \\
\text { site }\end{array}$ & p.? & $\begin{array}{c}\text { Likely } \\
\text { pathogenic (II) }\end{array}$ & \\
\hline Splicing & c. $1348-1 \mathrm{G}>\mathrm{A}$ & $\begin{array}{l}\text { Intron 8-splice } \\
\text { site }\end{array}$ & p.? & Pathogenic (Ic) & \\
\hline
\end{tabular}

$\S$ CLCN5 mutations also analyzed in patients' kidney biopsies.

\subsection{ClC-5, Megalin, and Cubilin Immunolabeling in DD1 Kidney Biopsies}

Renal tubular ClC-5 expression was analyzed by immunohistochemistry (IHC) in 10 patients carrying CLCN5 stop codon (frameshift and nonsense mutations) or missense mutations (Table 2). In control biopsies, $\mathrm{ClC}-5$ immunostaining was mainly apical and subapical (Figure 3). Our antibody has around $66 \%$ overall epitope sequence similarity to $\mathrm{ClC}-3$ and $\mathrm{ClC}-4$, which are both expressed in the membranes of intracellular organelles [23], so cross-reactivity can be expected. Immunolabeling for $\mathrm{ClC}-3, \mathrm{ClC}-4$, and $\mathrm{ClC}-5$ in serial sections of a control sample showed that tubular apical staining was almost exclusively attributable to $\mathrm{ClC}-5$ expression, while cytoplasmic staining was due largely to $\mathrm{ClC}-3$ and $\mathrm{ClC}-5$, and much less to $\mathrm{ClC}-4$ (Figure S1).

In DD1 biopsies, ClC-5 apical immunolabeling was negligible in most tubules, whatever the type of mutation (Figure 3). As expected, $\mathrm{ClC}-5$ expression was very significantly downregulated (Figure 4) in DD1 biopsies compared with control biopsies (median CTRL 8.69\% [Interquartile range (IQR) 1.94-15.97\%], DD1 0.01\% [IQR 0.00-0.12\%]; $p<0.01$ ).

Table 2 shows the morphometric findings on ClC-5 immunostaining for each mutation. Notably, two patients ( $\mathrm{Pt} 3$ and $\mathrm{Pt} 4)$ carried the same very premature nonsense mutation p.(Arg34*), but with a completely different pattern of expression: ClC-5 immunolabeling was completely absent in one, while in the other, it stained $0.12 \%$ of the whole biopsy area, which was more than in any of the other biopsies analyzed (Figure 3).

Analyzing megalin and cubilin immunofluorescence (IF) in the same patients (Figure 5) revealed that both receptors were significantly downregulated by comparison with control biopsies (median megalin: CTRL 4.52\% [IQR 3.64-8.39\%], DD1 1.67\% [IQR 0.09-3.91\%], $p=0.019$; median cubilin: CTRL $10.87 \%$ [IQR 1.54-19.85\%], DD1 1.01\% [IQR 0.83-2.67\%], $p=0.003$ ) (Figure 4). 
Table 2. Morphometric evaluation of tubular ClC-5 immunolabeling in 10 DD1 patients' kidney biopsies.

\begin{tabular}{cccccc}
\hline Patient & $\begin{array}{c}\text { CLCN5 } \\
\text { Mutation }\end{array}$ & $\begin{array}{c}\text { Age at Biopsy } \\
\text { (Years) }\end{array}$ & $\begin{array}{c}\text { Indication for } \\
\text { Biopsy }\end{array}$ & Histopathological Findings & $\begin{array}{c}\text { ClC-5 Immunolabeling } \\
\text { Morphometric Evaluation } \\
\text { (\% Positive Area) }\end{array}$ \\
\hline 1 & p.(Thr44fs) & 2 & Proteinuria & Minimal changes & 0.01 \\
\hline 2 & $\begin{array}{c}\text { p.(Lys231fs) } \\
\text { (novel) }\end{array}$ & 14 & Proteinuria & Normal & 0.00 \\
\hline 3 & p.(Arg34*) & 11 & $\begin{array}{c}\text { Nephrotic } \\
\text { syndrome }\end{array}$ & $\begin{array}{c}\text { Chronic interstitial nephritis with } \\
\text { global glomerulosclerosis }\end{array}$ & 0.12 \\
\hline 4 & p.(Arg34*) & 6 & Proteinuria & $\begin{array}{c}\text { Global glomerulosclerosis and } \\
\text { IgM nephropathy }\end{array}$ & 0.00 \\
\hline 5 & p.(Gln600*) & 6 & Proteinuria & $\begin{array}{c}\text { Tubulointerstitial injury with focal } \\
\text { glomerulosclerosis }\end{array}$ & 0.05 \\
\hline 7 & $\begin{array}{c}\text { p.(Ser203Trp) } \\
\text { (novel) }\end{array}$ & 3 & Proteinuria & Normal & 0.01 \\
\hline 8 & p.(Ser261Arg) & 4 & $\begin{array}{c}\text { Heavy } \\
\text { proteinuria }\end{array}$ & $\begin{array}{c}\text { Proliferative mesangial } \\
\text { glomerulonephritis }\end{array}$ & 0.07 \\
\hline 9 & $\begin{array}{c}\text { p.(Val308Met) } \\
\text { (novel) }\end{array}$ & 9 & Proteinuria & Normal & 0.01 \\
\hline 10 & p.(Trp547Arg) & 1 & Proteinuria & Normal & 0.08 \\
\hline
\end{tabular}

NA: not available.

CTRL

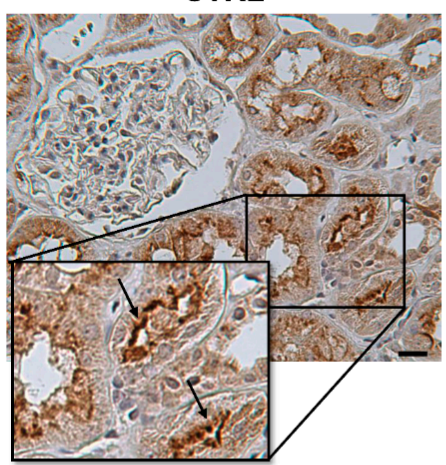

DD1 Pt3

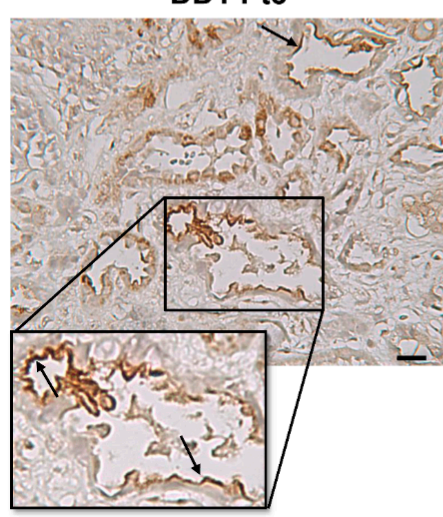

DD1 Pt9

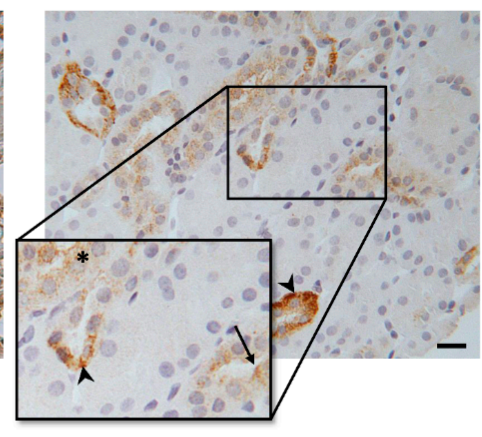

DD1 Pt4

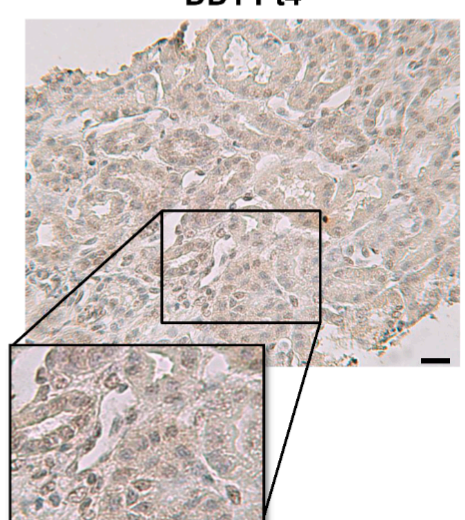

Figure 3. ClC-5 immunolabeling in control and DD1 kidneys. Representative images disclosing ClC-5 positivity in control and DD1 kidneys. In CTRL, ClC-5 staining was located mainly in tubular apical and subapical positions. In DD1 patients, some tubules presented basolateral or cytoplasmic ClC-5 positivity (Pt9), and very few showed apical staining (Pt9, Pt3). ClC-5 immunostaining was negligible in most DD1 tubules (Pt4), whatever the type of mutation. The asterisk indicates a cytoplasmic signal, arrows indicate apical and subapical signals, the arrowhead indicates a basolateral signal. Scale bar = $50 \mu \mathrm{m} . \mathrm{CTRL}=$ control, $\mathrm{Pt}=$ patient. 


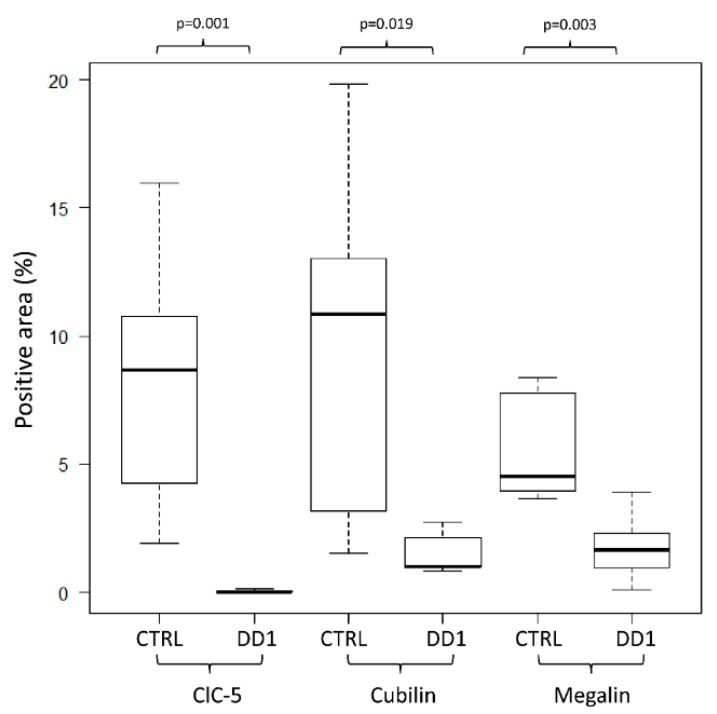

Figure 4. ClC-5, cubilin, and megalin quantitative analysis. Morphometric analysis showed a significant decrease in the percentage of positive area in kidneys of DD1 patients than in control kidneys for all molecules examined. Data were analyzed using the Mann-Whitney U-test. CTRL $=$ control.
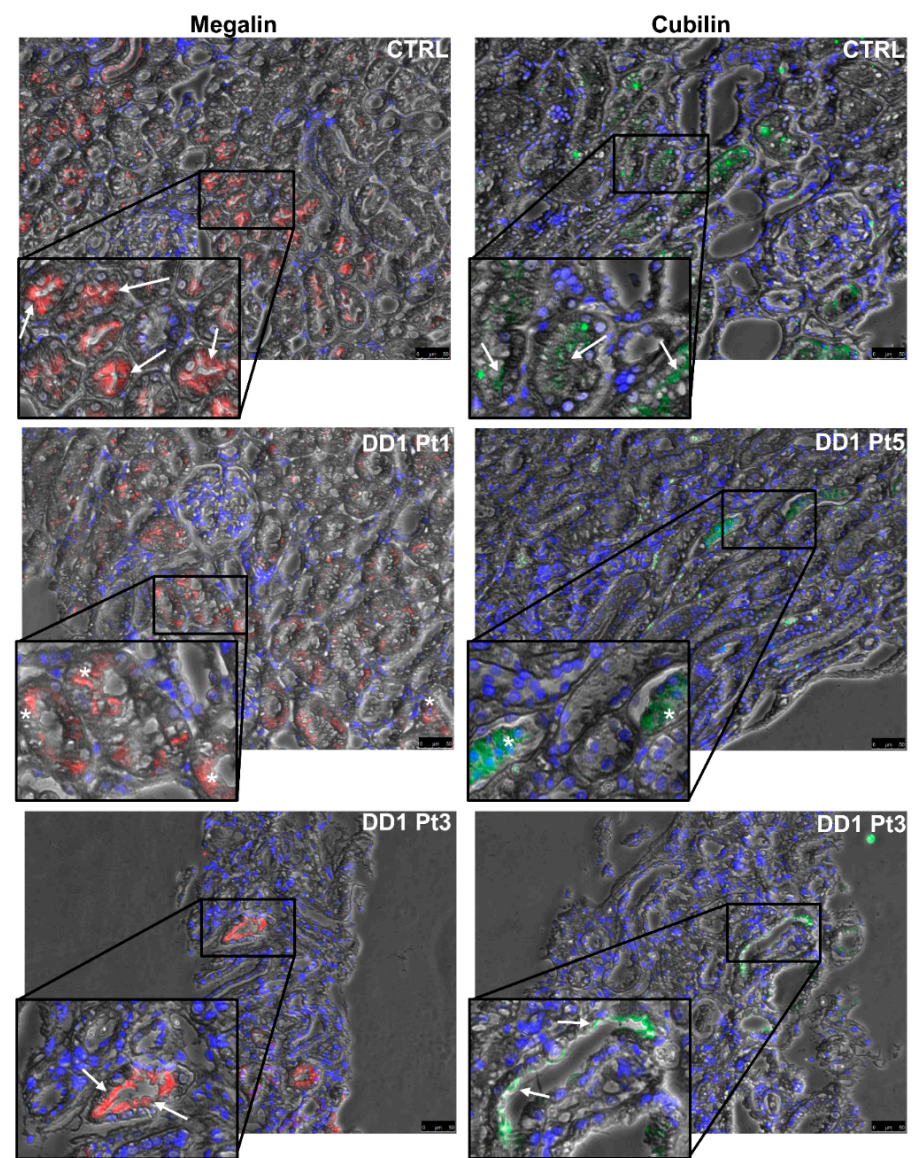

Figure 5. Megalin and cubilin immunolabeling in control and DD1 kidneys. Representative images disclosing megalin and cubilin positivity in control and DD1 kidneys. In CTRL, megalin (red) and cubilin (green) staining was located mainly in tubular apical and subapical positions. Immunolabeling for both receptors was rarely apical in DD1 patients (Pt3), while it was more frequently found in the cytoplasm (Pt1 and $\mathrm{Pt} 5)$. The asterisk indicates a cytoplasmic signal, arrows indicate apical and subapical signals. Blue indicates counter-staining of nuclei with 4',6-diamidino-2-phenylindole (DAPI). Scale bar $=50 \mu \mathrm{m}$. CTRL $=$ control, $\mathrm{Pt}=$ patient. 


\subsection{Whole Exome Sequencing (WES) Study}

Among CLCN5 negative patients, 34 underwent mutational screening of the OCRL gene, and 19 patients were found to not carry mutations. In eight out of 19 CLCN5 and OCRL-negative patients (four children and four adults), we performed WES.

We first searched for mutations in phenocopy genes. Known monogenic forms of nephrolithiasis and nephrocalcinosis as well as of proximal and distal tubulopathy, for a total of 62 genes including known genes of the PT endocytic pathway (Table S2), were firstly evaluated in these patients. Furthermore, the first 100 genes prioritized for their association with CLCN5 or OCRL genes using the Scalable kernel-based gene prioritization (SCUBA) were investigated [24] (Table S3).

Unexpectedly, in two children, we detected CLCN5 or OCRL known disease-causing mutations, p.(Lys231fs) and p.(Arg318Cys), respectively. If on one hand this finding was disturbing because it meant that by previous Sanger sequencing we had missed two causative mutations in the two known genes, on the other hand, it confirmed that our pool of DD3 cases was well representative of DD patients based on disease phenotype.

In four patients (three adults and one child), we detected 12 variants in three genes known to be associated either with monogenic forms of proximal renal tubulopathy (SLC3A1) or with monogenic syndromes involving proximal tubule dysfunction $(L R P 2, C U B N)$, as well as in novel genes not related to monogenic nephropathies (SLC17A1, SLC9A3, and PDZK1). These last genes could be candidates for DD-like phenotypes for their function in PT, and detected variants were predicted to be pathogenic or likely pathogenic by in silico tools (although with a different degree of concordance), except for one in the SLC17A1 gene (Table 3). Table S4 summarizes the four patients' clinical phenotypes.

In two adults patients (AMS and BDA), we detected biallelic likely pathogenic variants in SLC $3 A 1$ and LRP2 genes whose mutations are responsible for the recessive diseases Cystinuria (MIM\#220100) and Donnai-Barrow/Facio-oculo-acoustico-renal syndrome (DB/FOAR, MIM\#222448), respectively.

In AMS, we also identified a very rare missense variant classified as a variant of uncertain significance (VUS) in the SLC17A1 gene encoding sodium/phosphate cotransporter 1 (NPT1), which occurs at the apical pole of PTCs [25] and participates in renal urate export [26,27]. The same patient was found to be homozygous for the very rare nonsense variant $\mathrm{p}$.(Arg8*) in the PDKZ1 gene. This gene encodes the $\mathrm{Na}(+) / \mathrm{H}(+)$ exchange regulatory cofactor NHE-RF3, which is a PDZ domain-containing scaffolding protein and one of the key molecules of the urate transportsome $[28,29]$.

The already known pathogenic LRP2 mutation p.(Asp2054Asn) [30] was detected in AMV. In this patient, we also found an in-frame indel variant of the CUBN gene encoding for cubilin. CUBN gene mutations are known to cause Imerslund-Gräsbeck syndrome (IGS, MIM\#261100), which is an autosomal recessive disorder involving selective intestinal vitamin B12 malabsorption and LMWP. The p.(Val2347del) variant in CUBN is very rare (TOPmed 0.0000001); Mutation Taster (MT) and PROVEAN predicted its pathogenicity, and it was classified as VUS according to ACMG/AMP guidelines [22].

Among eight different $L R P 2$ uncommon coding variants with a minor allele frequency (MAF) $<0.05$ detected in our DD3 patients, four were identified in one patient (AMT) of which two were predicted to be pathogenic by in silico tools (Table 3). Similar to AMV, this patient carried an uncommon CUBN missense variant that was considered pathogenic by MT, PROVEAN, and DANN, but classified as benign according to ACMG/AMP guidelines. He also harbored a very rare variant in the SLC9A3 gene, which was predicted as pathogenic by in silico tools, and classified as VUS. The SLC9A3 gene encodes sodium/hydrogen exchanger 3 (NHE3), which is the main apical $\mathrm{Na}+\mathrm{H}+$ exchanger in adult kidneys [31], and part of the macromolecular endocytic complex at the brush border of PTCs [32,33]. 
Table 3. Candidate variants for DD3 phenotypes detected by whole-exome sequencing (WES).

\begin{tabular}{|c|c|c|c|c|c|c|c|c|}
\hline Pt ID & $\begin{array}{c}\text { Transcript } \\
\text { Level Variation }\end{array}$ & $\begin{array}{c}\text { Codon } \\
\text { Substitution }\end{array}$ & $\begin{array}{c}\text { Frequency } \\
\text { ExAC (European) }\end{array}$ & $\begin{array}{l}\text { Mutation } \\
\text { Taster }\end{array}$ & PROVEAN & DANN & ClinVar & $\begin{array}{c}\text { ACMG/AMP } \\
\text { Variant Interpretation }\end{array}$ \\
\hline \multicolumn{9}{|c|}{ SLC17A1 (NM_005074.3) } \\
\hline AMS & c. $1309 \mathrm{G}>\mathrm{A}$ & p.(Ala437Thr) & $\begin{array}{c}\text { rs1189357572 } \\
0.000003(\mathrm{GnomAD})(0.000008)\end{array}$ & Polymorphism (1.000) & $\begin{array}{l}\text { Neutral } \\
(-1.97)\end{array}$ & 0.967 & NA & VUS \\
\hline \multicolumn{9}{|c|}{ PDZK1 (NM_002614.4) } \\
\hline AMS & c. $22 \mathrm{C}>\mathrm{T}$ & $\begin{array}{c}\text { p.(Arg8*) } \\
\text { homozygous }\end{array}$ & $\begin{array}{c}\text { rs191362962 } \\
0.0001157(0.0001799)\end{array}$ & Disease causing automatic & NA & 0.998 & NA & VUS \\
\hline \multicolumn{9}{|c|}{ LRP2 (NM_004525.2) } \\
\hline BDA & c. $6727 \mathrm{C}>\mathrm{T}$ & p.(Arg2243*) & novel & $\begin{array}{l}\text { Disease causing automatic } \\
(1.000)\end{array}$ & NA & 0.996 & NA & Pathogenic (Ib) \\
\hline BDA & c. $242 \mathrm{~T}>\mathrm{A}$ & p.(Ile81Asn) & novel & Disease causing (1.000) & $\begin{array}{c}\text { Damaging } \\
(-4.62)\end{array}$ & 0.993 & NA & Likely pathogenic $(\mathrm{V})$ \\
\hline AMV & c. $6160 \mathrm{G}>\mathrm{A}$ & p.(Asp2054Asn) & $\begin{array}{c}\text { rs138269726 } \\
0.0011(0.0017)\end{array}$ & Disease causing (1.000) & $\begin{array}{l}\text { Neutral } \\
(-1.85)\end{array}$ & 0.999 & Pathogenic allele & Likely pathogenic (II) \\
\hline AMT & c. $2006 \mathrm{G}>\mathrm{A}$ & p.(Gly669Asp) & $\begin{array}{c}\mathrm{rs} 34291900 \\
0.0285(0.0434)\end{array}$ & Disease causing (1.000) & $\begin{array}{c}\text { Damaging } \\
(-5.44)\end{array}$ & 0.998 & Likely benign allele & Likely benign \\
\hline AMT & c.7894A>G & p.(Asn2632Asp) & $\begin{array}{c}\text { rs17848169 } \\
0.02951(0.0426)\end{array}$ & Disease causing (1.000) & $\begin{array}{c}\text { Neutral } \\
(-1.73)\end{array}$ & 0.452 & Likely benign allele & Likely benign \\
\hline \multicolumn{9}{|c|}{ SLC3A1 (NM_000341.4) } \\
\hline AMS & c. $680 \mathrm{G}>\mathrm{A}$ & p.(Arg227Gln) & $\begin{array}{c}\text { rs142469446 } \\
0.0002(0.0002)\end{array}$ & $\begin{array}{c}\text { Disease causing } \\
(1.000)\end{array}$ & $\begin{array}{l}\text { Neutral } \\
(-1.63)\end{array}$ & 1 & NA & Likely pathogenic (IV) \\
\hline AMS & c.797T >C & p.(Phe266Ser) & $\begin{array}{l}\text { rs141587158 } \\
0.003(0.004)\end{array}$ & Disease causing (1.000) & $\begin{array}{c}\text { Damaging } \\
(-4.7)\end{array}$ & 0.998 & NA & Likely pathogenic (IIIb \\
\hline \multicolumn{9}{|c|}{ CUBN (NM_001081.3) } \\
\hline AMT & c. $10265 C>T$ & p.(Thr3422Ile) & $\begin{array}{c}\text { rs1801230 } \\
0.01832(0.02829)\end{array}$ & Disease causing (1.000) & $\begin{array}{c}\text { Damaging } \\
(-2.94)\end{array}$ & 0.985 & Likely benign allele & Benign \\
\hline AMV & c.7040_7042del & p.(Val2347del) & $\begin{array}{c}\text { rs1279549461 } \\
\text { (TOPmed) } 0.0000001\end{array}$ & Disease causing (0.998) & $\begin{array}{c}\text { Deleterious } \\
(-9.81)\end{array}$ & NA & NA & VUS \\
\hline \multicolumn{9}{|c|}{ SLC9A3 (NM_004174.3) } \\
\hline AMT & c. $848 \mathrm{G}>\mathrm{A}$ & p.(Arg283His) & $\begin{array}{c}\text { rs146899318 } \\
0.00033(0.00036)\end{array}$ & $\begin{array}{c}\text { Disease causing } \\
(0.853)\end{array}$ & $\begin{array}{c}\text { Damaging } \\
(-3.85)\end{array}$ & 0.999 & NA & VUS \\
\hline
\end{tabular}

Pt: patient, ACMG/AMP: American College of Medical Genetics and American College of Pathologists, NA: not available, VUS: Variant of uncertain significance. 


\section{Discussion}

Dent disease 1 is a worldwide disease, and this is further confirmed by our cohort of patients which included persons from all over the word. More than 220 CLCN5 pathogenic mutations have been reported so far. Mutations were found scattered along all exons of the gene and in different protein domains [9,34-45]. Mansour-Hendili et al. [9] reported that the majority were missense and frameshift mutations (33.33\% and $29.05 \%$ respectively) followed by nonsense mutations $(17.52 \%)$, splicing mutations (12.39\%), and large deletions (4.70\%). In our cohort of patients, missense and frameshift mutations were also the most frequent, but with a lower proportion ( $38 \%$ and $25 \%$ respectively), while we observed more nonsense mutations compared to the previously reported data $(23 \%)$.

In our study, DNA sequence analysis of the CLCN5 gene revealed 50 different mutations, 23 of which have never been described before. ACMG/AMP guidelines classify the nine missense novel mutations in CLCN5 as likely pathogenic. They were mapped onto ClC-5 protein domains (Table 1).

The p.(Ile173Lys) missense mutation is in the D helix, which is one of the four helixes (D, F, N, and $\mathrm{R}$ ) brought together near the channel center to form the $\mathrm{Cl}$-selectivity filter [46] and consequently believed to alter $\mathrm{ClC}-5$ conductance.

The p.(His731Pro) missense mutation affects the ClC-5 carboxy-terminus cytoplasmic domain. All eukaryotic $\mathrm{ClC}$ s have a large cytoplasmic $\mathrm{C}$-terminus containing a pair of cystathionine beta-synthase (CBS) domains. Several authors have shown that CBS domains are involved in regulating the activity of $\mathrm{ClCs}$, including $\mathrm{ClC}-5$ [47-49]. Mutations affecting the two CBS domains were reported correctly targeted to the plasma membrane and early endosomes, but with altered $\mathrm{ClC}-5$ electrical activity [14]. The nonsense mutation p.(Arg718*) truncating the ClC-5 protein near the C-terminus reportedly results in ER retention, underscoring the importance of the C-terminus in passing protein quality control in ER [50]. These findings suggest that truncated $\mathrm{ClC}-5$ proteins at the $\mathrm{C}$-terminus could cause function loss through defective protein processing. However, three different truncated mutations at the C-terminus-p.(Tyr617*), p.(Arg648*), and p.(Arg704*)—targeted the cell surface (albeit only one with residual activity) [50], so we cannot say whether our stop codon mutations at the C-terminus of ClC-5 protein (Table 1) could exhibit residual activity targeting the plasma membrane.

The p.(Ser203Trp) missense mutation affects the E helix, whose role in ClC-5 function is still unclear. The nearby p.(Leu200Arg) mutation reportedly produced a loss of $\mathrm{Cl}$ - conductance [1], and the p.(Ser203Leu) was found to cause current failures due to ER retention [50]. Taken together, these findings indicate that the p.(Ser203Trp) mutation is probably pathogenic.

Six missense mutations map in the major helixes (B, H, I, O, P, and Q) involved in dimer interface formation $[9,46]$, or in the intervening loops, suggesting an impaired physical contact between the two subunits that might disrupt proper pore configuration [50,51]. In addition, for the p.(Ala540Val), a pathogenic missense in the same position in a Dent family from New Zealand has already been reported [38], confirming the possible damaging role of the alteration of this residue. The p.(Ser270Asn) missense mutation maps in the loop between helixes H and I, near the "proton glutamate" (Glu 268), which is crucial to the $\mathrm{Cl} / \mathrm{H}+$ transport function [9]. Since the p.(Ser270Arg) mutation was reportedly associated with chloride current abolition [52], we hypothesize a similar effect of this new mutation.

Very few studies investigated ClC-5 expression in kidney biopsies [10,53]. We analyzed ClC-5 protein expression in kidney biopsies from 10 patients carrying three novel and seven known CLCN5 mutations and in eight control biopsies. In controls, $\mathrm{ClC}-5$ immunolabeling was mainly apical and subapical in tubular cells, and it was not co-localized with $\mathrm{ClC}-3$ or ClC-4 staining. The few studies on ClC-5 expression in human kidney reported similar staining findings [10,53], which are justified by the well-accepted CIC-5 localization in early and recycling endosomes and the plasma membrane [54,55].

Our study is the first to demonstrate the loss of ClC-5 protein expression in DD1 kidneys. However, an apical staining was detected in very few tubules in 7/10 DD1 biopsies, including those with the novel p.(Val308Met) and p.(Ser203Trp) mutations. Therefore, we speculate that the expression of these $\mathrm{ClC}-5$ mutants is regulated post-translationally, and mutated proteins can very rarely reach the plasma membrane. This is consistent with previous findings in ClC-5 mutant models. Both missense 
and nonsense $\mathrm{ClC}-5$ mutants could be either targeted to early endosomes or plasma membrane, but with a limited activity, or confined to the ER [50]. In fact, some DD1 tubules were only labeled at the basolateral pole (probably a sign of ER retention) (Figure $3 \mathrm{Pt} 9$ ).

Apical staining was unexpectedly detected for the very premature truncated ClC-5 protein at codon 34. Premature stop codons (PSCs) account for one in two CLCN5 mutations, and cause three distinct molecular alterations: (1) the production of a truncated, usually non-functional, protein; (2) degradation of the transcripts containing PSCs via the nonsense-mediated decay (NMD) pathway; and (3) exon skipping due to alternative cryptic acceptor or donor sites being used in the exon encompassing the stop codon [56]. The first molecular change can be excluded, because our ClC-5 antibody recognized an epitope at the C-terminus of the protein. The second and third might apply because (1) NMD may occasionally be bypassed when translational read-through allows the decoding of stop codons as sense codons, thus enabling protein translation; (2) PSCs can also prompt exon skipping by altering exonic splicing enhancer (ESE) or exonic splicing silencer (ESS) motifs. PSCs have even been found to be statistically inclined to induce exon skipping more than other exon mutations [57]. If this is true of the p.(Arg34*) mutation, we can expect exon skipping to be in frame, thus enabling complete protein synthesis and allowing the mutated protein to be detected by immunolabeling. However, such explanations for this $\mathrm{ClC}-5$ mutant protein's presence in one biopsy should be considered with caution, as the ClC-5 protein was not found in most tubules, nor in another biopsy carrying the same mutation. This could mean that how PSCs are processed by cell transcriptional and translational apparatus might depend on the context (meaning the cell environment and/or the genomic context).

As in Clcn5 knock-out (KO) animal models [58], ClC-5 loss in human kidney causes defective cubilin and megalin recycling, leading to LMWP. All the ClC-5 mutants studied here triggered both their defective expression at the brush border of PTCs and their downregulation. The presence of a megalin signal at the apical border of some tubules in the biopsy carrying the p.(Arg34*) mutation (Figure 5, Pt3) suggests a residual ClC-5 activity enabling a normal endocytic process and consequent megalin recycling.

Few studies have examined megalin and cubilin expression in DD1. Urinary megalin excretion was found to be significantly lower in DD1 patients than in normal individuals [59]. IHC on kidney biopsies from two patients carrying different $C L C N 5$ mutations revealed a defective megalin, cubilin, and Dab2 expression in PTCs $[60,61]$. Studies on megalin recycling in conditionally immortalized proximal tubular epithelial cell lines from three patients with CLCN5 mutations showed defects in cell surface expression and internalization [62]. Our data definitively corroborate previous findings and suggest that a reduced intracellular megalin and cubilin synthesis may also contribute to their defective apical exposure.

Approximately one in four DD patients have no CLCN5 or OCRL gene mutations. Whether mutations in a third, as yet unknown gene can cause DD3 remains to be seen, but-judging from our WES study on six DD3 patients-this seems unlikely. Instead, as we previously suggested [63], WES data point to DD3 patients having atypical phenotypes of known hereditary nephropathies or blended phenotypes. In fact, we identified in two patients (AMS and BDA) biallelic likely pathogenic variants in two genes (SLC3A1, LRP2) whose mutations are known to cause cystinuria and DB/FOAR. Our findings suggest that probably these patients were misdiagnosed as DD because of the presence renal Fanconi syndrome. Indeed, several disorders are caused by mutations of genes coding for components of the endolysosomal system in the PT. Besides CLCN5 (DD1) and OCRL (Lowe syndrome and Dent disease type 2) genes, they include LRP2 (DB/FOAR), CUBN, AMN (Imerslund-Gräsbeck syndrome), and CTNS (nephropathic cystinosis). Typically, these recessive disorders cause proximal tubular dysfunction and lead to inappropriate urinary loss of LMW proteins and solutes (e.g., phosphate, glucose, amino acids, urate), and they often lead to renal failure. The clinical entity of generalized proximal tubular dysfunction is referred to as renal Fanconi syndrome.

However, apart from BDA who was found to carry biallelic pathogenic variants in the LRP2 gene and, for this reason, and after a careful clinical revaluation, was assessed to suffer from an atypical form 
of DB/FOAR syndrome [64], the other patient (AMS) did not suffer from cystinuria, despite carrying biallelic variants in the SLC3A1 gene that were classified as likely pathogenic according to ACMG/AMP variant interpretation. Indeed, in this patient, the urinary level of cysteine was found to be normal even after repeated measurements. Two hypotheses may explain these findings: (1) the variants may be hypomorphic, thereby allowing a limited gene product activity, and (2) the two variants are in the same allele (complex allele), although their MAF was highly different, suggesting the absence of a linkage disequilibrium.

Instead, what appears relevant from this study is finding in three patients (comprising AMS) possible pathogenic variants in more than one gene connected in functional networks (PDZK1, SLC17A1, CUBN, SLC3A9, and LRP2), which we considered important for explaining patients' phenotypes, thus suggesting digenic or oligogenic disorders.

The major finding of WES study is the discovery in AMS of a homozygous truncating mutation in the PDZK1 gene. This is a new gene that has never been related before to human diseases, although it is one of the loci of strongest effect on serum urate level and gut [65-67]. NHE-RF3 encoded by PDZK1 is a major scaffolder protein in the brush border of kidney PTCs [68], interacting through its PDZ domain with key molecules of urate transport, including NPT1 [29]. Furthermore, NHE-RF3 is one of the several proteins interacting with the type-2a sodium phosphate cotransporter (NaPi-2a), which is the major inorganic phosphate cotransporter of the PTCs [69]. Targeted disruption of the Pdzk1 gene by homologous recombination in mice induced modulation of the expression of selective ion channels in the kidney, including NaPi-2a. The steady-state levels of NaPi-2a were found to be reduced under a phosphorus (Pi)-rich diet, and this was paralleled by higher urinary total and fractional Pi excretion [69]. In these $\mathrm{KO}$ mice, serum urate was not measured, nor were urate transporters investigated. However, urine and serum analysis did not reveal any significant difference between $\mathrm{KO}$ and wild-type mice except for a significant increase in the cholesterol levels [69]. Interestingly, in Pdzk1 KO mice under a high-Pi diet, the PDZ scaffolding protein NHE-RF1 was increased at the bush border of proximal tubules. NHE-RF1 was demonstrated to localize with megalin in the brush border, because it bounds to its internal C-terminal PDZ binding motif [70]. It was also showed that NHE-RF1 silencing in PTCs increased megalin expression [70].

In the same patient, we also detected a very rare missense variant in the SLC17A1 gene, which is classified as VUS due to its extreme rarity in the human population (data from gnomAD: 1 allele out of 250846). The SLC17A1 gene is one of the loci associated with serum urate level and gout [71] and encodes NPT1, which is a Cl-dependent urate transport interacting with NHE-RF3 encoded by the PDZK1 gene [26]. The clinical phenotype of patient AMS involves multiple tubular defects (particularly hyperphosphaturia, hypercalciuria, and severe hypouricemia), which might be consistent with a partial renal Fanconi syndrome and had led to a clinical suspicion of renal hypouricemia (MIM\#220150 and 612076) and atypical DD. By WES, we excluded the presence of pathogenic variants in both SLC22A12 and SLC2A9 genes encoding URAT1 and GLUT9, respectively. It is tempting to speculate that the PDZK1 and the SLC17A1 gene variants might have had a role in determining AMS clinical phenotype for their direct interaction with urate and phosphate transport. Family studies will help clarify these aspects.

Since megalin and cubilin PTC expression is altered in DD1, it is conceivable that $L R P 2$ and/or CUBN mutations can cause or contribute to a DD-like nephropathy. WES results seem to support this hypothesis. In addition to BDA, who has already been described as carrying biallelic mutations in the LRP2 gene [64], AMV was also found to carry a known pathogenic LRP2 allele and a very rare inframe deletion in the $C U B N$ gene. $C U B N$ variants have recently been associated with proteinuria with no signs of IGS. It was shown that a homozygous frameshift mutation in exon 53 of CUBN (p.Ser2785fs) only caused proteinuria [72]. Moreover, a missense variant in exon 57 (p.Ile2984Val) was associated with albuminuria [73]. Mutations in the CUBN gene cause IGS apparently only when they affect the cubilin-amnionless interaction domain (exons 1-20) or the IF-Cbl binding site (exons 21-29) [74]. In our 
patient, CUBN mutation is localized in exon 46. Follow-up showed that our patient's LMWP was intermittent while his proteinuria started at 1 year old and ranged between 0.4 and $1 \mathrm{~g} / 24 \mathrm{~h}$.

True digenic inheritance (DI) is the simplest form for oligogenic disease [75], but it is also encountered when pathogenic mutations responsible for two different diseases are co-inherited, leading to a blended phenotype [76]. The two heterozygous mutations in the LRP2 and CUBN genes, encoding proteins working close together on the same endocytic pathway, might plausibly be responsible for patient AMV's disease phenotype. Further studies on his kidney biopsy and/or urinary proteoma might confirm this hypothesis. Family studies may help to solve these questions.

We detected two LRP2 coding variants associated with two likely pathogenic missense variants in the CUBN and SLC9A3 genes in the genome of a single patient (AMT). It is noteworthy that these genes respectively encode megalin, cubilin, and NHE3, which are located-together with ClC-5, amnionless, and Dab2 - at the cell surface of PTCs, forming its endocytic apparatus [54,55].

SLC9A3 homozygous or compound heterozygous disease-causing mutations have recently been reported in nine patients from eight families with congenital secretory sodium diarrhea (MIM\#616868) [77]. No association has been found as yet between $S L C 9 A 3$ variants and renal proximal tubulopathies, but a defective Nhe3 exposure was found in Clcn5 KO mice [55,78]. Studies by Gekle et al. [33] support a crucial role for NHE3 in proximal tubular receptor-mediated endocytosis by demonstrating in Nhe3 KO mice that Nhe3 deficiency led to a reduced protein reabsorption: the urinary protein patterns resembled those of mice deficient in megalin or $\mathrm{ClC}-5$. Recent evidence also highlights the importance of NHE3 for calcium reabsorption. Nhe3 $\mathrm{KO}$ mice revealed significant urinary calcium wasting and a low cortical bone mineral density and trabecular bone mass [79].

The genetic data of the AMT patient are puzzling and raise some questions. With the advent of high-throughput sequencing, we are bound to discover more patients suffering from oligogenic diseases and learn more about how complex interactions between allelic and locus heterogeneity affect disease phenotypes [80]. The presence of multiple coding variants in the same gene, either in cis or in trans, may also conceivably cause defective protein functioning, although this needs to be demonstrated in animal and in vitro models [81]. The genotype-phenotype correlation in the AMT patient is worth investigating, because it seems to reveal such an impact on disease phenotype. This patient was 26 years old when referred to a nephrologist for kidney stones. His height $(158 \mathrm{~cm})$ and weight $(42 \mathrm{~kg}$ ) were below the third percentile. His renal phenotype mainly featured proximal tubulopathy manifesting as Fanconi syndrome with LMWP, hypercalciuria, hyperphosphaturia, glycosuria, natriuresis, and hypercitraturia. Therefore, the patient's presenting phenotype was mainly related to an impaired renal calcium and phosphate metabolism. WES detected no relevant variants in genes known to be responsible for monogenic forms of nephrolithiasis and renal tubulopathies. We hypothesized that the AMT patient's phenotype was due to the variants in LRP2, CUBN, and SLC9A3, whose products work on the same cellular pathways as $\mathrm{ClC}-5$, or pathways related thereto, but this hypothesis needs to be evaluated by in vitro studies. From the point of view of the referring clinicians, tubular abnormalities might be a real challenge: indeed, clinical characteristics of different diseases sometimes overlap, and a full-blown classical phenotype (in the case of AMS, a renal Fanconi syndrome) is rare. Therefore, when multiple tubular defects (i.e., alteration in tubular handling of 2-4 different solutes) coexist, the chance of a blended phenotype becomes more plausible, and a next-generation sequencing (NGS) approach might be a good strategy to identify multiple (and possibly interacting) genetic defects that may explain each individual phenotype.

\section{Material and Methods}

\subsection{Patients}

\subsubsection{DNA Samples}

From 2006 to 2018, DNA samples were collected from 158 unrelated pediatric and adult males with clinically suspected DD according to the criteria described in our previous study [82]. Patients should 
have encountered at least two of the above-mentioned criteria for being referred to our laboratory for a molecular diagnosis. Since proteinuria was recently reported as one of the DD symptoms in concomitance with signs of incomplete Fanconi tubulopathy [83], and because of the cost of urinary assessment of LMW proteins, we decided to include in the diagnostic workflow also patients presenting with proteinuria, although in the absence of documented LMWP. Informed consent to the genetic study was obtained from all probands or their parents.

DNA samples from eight patients (four children and four adults) with no detectable CLCN5 or OCRL gene mutations underwent WES. The selection was based on the presence of a likely DD phenotype (i.e., the presence of LMWP and/or proteinuria, hypercalciuria, and at least one of the following: nephrocalcinosis, kidney stones, hypophosphataemia, renal failure, aminoaciduria, rickets, or a positive family history) with or without extra-renal symptoms. The study was approved by Padua University Hospital's Ethical Committee, protocol 0028285 (11 May 2016)

\subsubsection{Biopsies}

Ten kidney biopsies were collected from patients carrying nine different CLCN5 mutations (Table 2). All biopsies were performed for diagnostic purposes and available for immunolabeling studies subject to informed consent.

Eight control cortical tissues were obtained from nephrectomies for renal cancer (sites remote from the tumor-bearing renal tissue), disclosing a normal morphology and no immunofluorescence. The study was approved by Padua University Hospital's Ethical Committee, protocol 0007452 (1 February 2018).

\subsection{Sanger Sequencing}

CLCN5 gene mutation analysis was performed by Sanger sequencing. Genomic DNA was extracted from peripheral blood using the QIAamp DNA Blood Minikit (Qiagen, Milan, Italy) according to the manufacturer's instructions. The primers and PCR conditions for amplifying the CLCN5 gene-coding region and intron-exon boundaries are described elsewhere [82]. The PCR products were analyzed using the Bioanalyzer 2100 (Agilent Technologies, Milan, Italy) and purified with the MinElute PCR Purification Kit (Qiagen, Milan, Italy). Sanger sequencing was done with the BigDye Terminator v1.1 Cycle Sequencing Kit (ThermoFisher Scientific, Milan, Italy) and the ABI-PRISM 3100 Genetic Analyzer (ThermoFisher Scientific, Milan, Italy). The nomenclature of mutations is based on the CLCN5 cDNA sequence NM_0000844. Missense and splicing mutations were interpreted using the Mutation Taster (MT) [84], and classified according to the American College of Medical Genetics and American College of Pathologists (ACMG/AMP) variant classification guidelines [22]. Mutations were confirmed by sequencing a second independent PCR product.

\subsection{Whole-Exome Sequencing (WES)}

WES was performed at Padua University's Centro di Ricerca Interdipartimentale per le Biotecnologie Innovative (CRIBI) sequencing center using the Ion Proton System (ThermoFisher Scientific, Milan, Italy), obtaining an average reads coverage of 80X for each sample. Data were analyzed as suggested by the manufacturer, with read alignment using TMAP and variant calling with TSVC, which are both included in the Ion Proton Suite (v 5.0). QueryOR (http://queryor.cribi.unipd.it, accessed on 27 November 2019) [85] was used to analyze and prioritize short-nucleotide variants (SNV). This web-based query platform enables quick, easy, in-depth variant prioritization by aggregating several functional annotations of both genes and variants. The prioritization strategy entails a ranking that sorts results by the number and weight of the criteria met (see below).

Two main approaches were initially used to identify the most promising variants: (1) a genecentered search, considering known details of genes and associated pathways, and information about the disease and related disorders; and (2) a variant-centered search, focusing on the intrinsic characteristics 
of variants, such as type (indel, snp, mnp), codon effect (frameshift, missense, and nonsense variants), and genomic position.

In a subsequent prioritization step, variants were ranked by sequencing coverage, minor allele frequency (MAF) values $\leq 0.05$, and predicted possible-probable deleteriousness. For this purpose, QueryOR provides coding variant predictions based on several tools, including the well-known SIFT, PolyPhen2, and MT, and the more recent PROVEAN, CADD, and DANN scores [84,86-90]. Sanger sequencing was used to validate variants identified by the in silico prioritization strategy during WES. Table S5 shows the gene names, NCBI reference sequences, primers, and PCR amplification conditions.

Identified variants were checked against relevant database such as Clinvar (https://www.ncbi. nlm.nih.gov/clinvar/, accessed on 27 November 2019) and The Human Gene Mutation Database (HGMD) (http://www.hgmd.cf.ac.uk/ac/index.php, accessed on 27 November 2019), and were classified according to ACMG/AMP guidelines [22].

\subsection{Immunohistochemistry (IHC)}

IHC was conducted on formalin-fixed, paraffin-embedded sections using an indirect immunoperoxidase method. Specimens were treated as previously described [91], and incubated overnight with rabbit anti-human ClC-5 (Sigma-Aldrich, Milan, Italy, cat. HPA000401) diluted 1:200, goat anti-human ClC-3 (Santa Cruz Biotechnologies, Heidelberg, Germany, cat. sc-17572) diluted 1:150, and rabbit anti-human ClC-4 (Sigma-Aldrich, Milan, Italy, cat. HPA063637) diluted 1:50 in PBS at $4{ }^{\circ} \mathrm{C}$ in a humidified chamber. A donkey anti-goat IgG-HRP secondary antibody (Santa Cruz Biotechnologies, Heidelberg, Germany, cat. sc-2020) diluted 1:100 was used for ClC-3. Immunolabeling specificity was confirmed by incubating without any primary antibody. Images were acquired with the Diaplan light microscope (Leitz, Como, Italy) and 20X/0.45 objective using a Micropublisher 5.0 RTV camera (Teledyne QImaging, Surrey, BC, Canada).

\subsection{Immunofluorescence (IF)}

IF analyses were performed on serial sections of kidney biopsies. Samples were treated as previously described [92] and incubated overnight with primary antibody (sheep anti-human cubilin [R\&D Systems, Minneapolis, MN, USA, cat. AF3700], rabbit anti-human megalin [LS-Bio, Seattle, WA, USA, cat. LS-B105]) diluted 1:100 in PBS $5 \%$ BSA at $4{ }^{\circ} \mathrm{C}$. Sections were incubated with the appropriate fluorescent secondary antibody [92]. Nuclei were counterstained with 4',6-diamidino-2-phenylindole (DAPI). Negative controls were run by omitting the primary antibody. Images were acquired with a DMI6000CS-TCS SP8 fluorescence microscope (Leica Microsystems, Milan, Italy) with a 20X/0.4 objective using a DFC365FX camera (Leica Microsystems, Milan, Italy) and analyzed with the LAS-AF software (Leica Microsystems, Milan, Italy).

\subsection{Morphometric Analysis}

ClC-5, megalin, and cubilin signals on kidney biopsies were quantified by morphometric analysis using Image-Pro Plus 7.0 (Media Cybernetics, Abingdon, United Kingdom). Signals were acquired at 200X with the same time exposure, gain, and intensity for all patients, and quantified excluding the glomerular compartment. For $\mathrm{ClC}-5$, only apical or subapical tubular staining was considered as positive. Quantities were expressed as the mean area covered by pixels (\%).

\subsection{Statistical Analysis}

Non-parametric tests (Mann-Whitney U-test) were used due to the small sample size. Results with $p<0.05$ were considered significant and given as median \pm IQR. All analyses were performed with R software version 3.5.1 (R Foundation for Statistical Computing, Vienna, Austria) [93]. 


\section{Conclusions}

By describing 23 novel CLCN5 mutations, this study extends the allelic heterogeneity of DD1. Our results on DD1 kidney biopsies provide evidence that ClC-5 is lost in PTCs, and this, in turn, leads to a defective trafficking of megalin and cubilin in these cells.

Using WES to investigate DD3 patients, we did not identify the supposed third Dent diseasecausing gene. Instead, our study suggests that likely pathogenic variants in genes encoding components of the endocytic apparatus of tubular cells (megalin, cubilin, NHE3, and NHE-RF3) may have determined DD3 phenotypes. However, except for one patient in whom we identified a known monogenic disease, in the other patients, the presence of variants in more than one gene related in functional networks suggest that we are probably facing oligogenic disorders. Furthermore, our study suggests that DD3 patients are a pool of patients with DD-like phenotypes, which may present atypical phenotypes of known hereditary nephropathies or blended phenotypes.

Supplementary Materials: Supplementary materials can be found at http:/www.mdpi.com/1422-0067/21/2/516/s1. Figure S1: ClC-5, ClC-4 and ClC-3 immunolabeling in serial sections of a control kidney. Tubular staining was almost exclusively apical (arrows) for ClC-5, while cytoplasmic staining (arrowheads) was seen for ClC-3, and $\mathrm{ClC}-5$ and much less for ClC-4. Scale bar $=50 \mu \mathrm{m}$. Table S1: Clinical phenotypes of 20 patients carrying novel CLCN5 mutations. Table S2: List of phenocopy genes. Table S3: List of the genes prioritized according to scalable kernel-based gene prioritization (SCUBA) [24]. Table S4: DD-like phenotype of patients carrying likely pathogenic variants as detected by whole exome sequencing. Table S5: PCR primer sequences and amplification conditions.

Author Contributions: Study conception, design of experiments, and critical review of the results: F.A., G.V., M.C., L.B.; WES experiments: L.B.; WES data analyses: F.A., L.B., and L.T.; Sanger experiments: L.G., L.T., and M.C.; IHC experiments: M.C. and G.P.; IF experiments: L.G. and G.P.; Statistical analysis: L.G.; Morphometric analysis: M.C. and D.D.P.; Drafting of the paper: F.A., L.B., L.G., and M.C.; Supervision of clinical cases and clinical data collection: D.D.P., V.C. and C.M.; Histopathological data reporting on kidney biopsies: L.M., M.G., L.P., F.P., and F.A. F.A. conceived the paper's structure, supervised its writing, and thoroughly reviewed all content. All authors have read and agreed to the published version of the manuscript.

Funding: This work was supported by the University of Padua, Strategic Project BIOINFOGEN prot. STPD11F33L, and by the Rare Kidney Stone Consortium (U54DK83908), which is part of the Rare Diseases Clinical Research Network (RDCRN), an initiative of the Office of Rare Diseases Research (ORDR), NCATS, as Grant number PAD-182824 awarded to L.G. This consortium is funded through collaboration between NCATS, and the National Institute of Diabetes and Digestive and Kidney Diseases.

Acknowledgments: This work was performed with the contribution of the Italian Network of Dent Disease researchers: Gian Marco Ghiggeri and Giancarlo Barbano (Division of Nephrology, Dialysis and Kidney Transplantation, G. Gaslini Pediatric Institute, Genova), Francesco Emma and Gianluca Vergine (Division of Nephrology and Dialysis, Bambin Gesù Pediatric Hospital, Rome), Giuseppe Vezzoli (Division of Nephrology, Dialysis and Hypertension, IRCCS San Raffaele Hospital, Milan), Marilena Cara (Nephrology Division, Camposampiero General Hospital, Camposampiero) Gabriele Ripanti (Pediatrics and Neonatology Division, San Salvatore Hospital, Pesaro), Anita Ammenti (Pediatric Institute, University of Parma), Licia Peruzzi (Division of Nephrology, Dialysis and Transplantation, Regina Margherita Hospital, Turin), Giacomo Colussi (Nephrology Unit, Varese Hospital, Varese), Mario Giordano (Nephrology and Pediatric Dialysis, Pediatric Hospital, Bari) Maria Rosa Caruso (Nephrology Unit, Bergamo Hospital, Bergamo), Ilse Maria Ratsch (Pediatric Institute, University of Ancona), Giuseppina Marra and Fabio Paglialonga (Nephrology Unit, IRCCS Foundation, Ca' Granda Ospedale Maggiore Policlinico, University of Milan), Angela La Manna (Department of Pediatrics, 2nd University of Napoli), Caterina Canavese (Nephrology and Kidney Transplantation Unit, Department of Translational Medicine, University of Piemonte Orientale (UPO), Novara), Diego Bellino (Division of Nephrology, Dialysis and Kidney Transplantation, San Martino University Hospital, Genova), Luisa Murer (Pediatric Nephrology, Dialysis and Transplant Unit, Department of Women's and Children's Health, Padua University Hospital), Milena Brugnara (Pediatric Division, Department of Life and Reproduction Sciences, University of Verona), Andrea Pasini and Claudio La Scola (Nephrology and Dialysis Unit, Department of Pediatrics, Azienda Ospedaliero Universitaria Sant'Orsola-Malpighi, Bologna).

Conflicts of Interest: The authors declare no conflict of interest. 


\section{References}

1. Lloyd, S.E.; Pearce, S.H.; Fisher, S.E.; Steinmeyer, K.; Schwappach, B.; Scheinman, S.J.; Harding, B.; Bolino, A.; Devoto, M.; Goodyer, P.; et al. A common molecular basis for three inherited kidney stone diseases. Nature 1996, 379, 445-449. [CrossRef] [PubMed]

2. Thakker, R.V. Pathogenesis of Dent's disease and related syndromes of X-linked nephrolithiasis. Kidney Int. 2000, 57, 787-793. [CrossRef] [PubMed]

3. Wrong, O.M.; Norden, A.G.; Feest, T.G. Dent's disease; a familial proximal renal tubular syndrome with low-molecular-weight proteinuria, hypercalciuria, nephrocalcinosis, metabolic bone disease, progressive renal failure and a marked male predominance. Q. J. Med. 1994, 87, 473-493.

4. Reinhart, S.C.; Norden, A.G.; Lapsley, M.; Thakker, R.V.; Pang, J.; Moses, A.M.; Frymoyer, P.A.; Favus, M.J.; Hoepner, J.A.; Scheinman, S.J. Characterization of carrier females and affected males with X-linked recessive nephrolithiasis. J. Am. Soc. Nephrol. 1995, 5, 1451-1461. [CrossRef] [PubMed]

5. Lloyd, S.E.; Gunther, W.; Pearce, S.H.; Thomson, A.; Bianchi, M.L.; Bosio, M.; Craig, I.W.; Fisher, S.E.; Scheinman, S.J.; Wrong, O.; et al. Characterization of renal chloride channel, CLCN5, mutations in hypercalciuric nephrolithiasis (kidney stones) disorders. Hum. Mol. Genet. 1997, 6, 1233-1239. [CrossRef] [PubMed]

6. Jentsch, T.J.; Günther, W.; Pusch, M.; Schwappach, B. Properties of voltage-gated chloride channels of the ClC gene family. J. Physiol. 1995, 482, 19S-25S. [CrossRef]

7. Thakker, R.V. Chloride channels cough up. Nat. Genet. 1997, 17, 125. [CrossRef]

8. Picollo, A.; Pusch, M. Chloride/proton antiporter activity of mammalian CLC proteins ClC-4 and ClC-5. Nature 2005, 436, 420-423. [CrossRef]

9. Mansour-Hendili, L.; Blanchard, A.; Le Pottier, N.; Roncelin, I.; Lourdel, S.; Treard, C.; González, W.; Vergara-Jaque, A.; Morin, G.; Colin, E.; et al. Mutation update of the CLCN5 gene responsible for Dent disease 1. Hum. Mutat. 2015, 36, 743-752. [CrossRef]

10. Jouret, F.; Igarashi, T.; Gofflot, F.; Wilson, P.D.; Karet, F.E.; Thakker, R.V.; Devuyst, O. Comparative ontogeny; processing; and segmental distribution of the renal chloride channel; ClC-5. Kidney Int. 2004, 65, 198-208. [CrossRef]

11. Christensen, E.I.; Devuyst, O.; Dom, G.; Nielsen, R.; Van Der Smissen, P.; Verroust, P.; Leruth, M.; Guggino, W.B.; Courtoy, P.J. Loss of chloride channel ClC-5 impairs endocytosis by defective trafficking of megalin and cubilin in kidney proximal tubules. Proc. Natl. Acad. Sci. USA 2003, 100, 8472-8477. [CrossRef] [PubMed]

12. Gunther, W.; Luchow, A.; Cluzeaud, F.; Vandewalle, A.; Jentsch, T.J. ClC-5, the chloride channel mutated in Dent's disease; colocalizes with the proton pump in endocytically active kidney cells. Proc. Natl. Acad. Sci. USA 1998, 95, 8075-8080. [CrossRef] [PubMed]

13. D'Antonio, C.; Molinski, S.; Ahmadi, S.; Huan, L.J.; Wellhauser, L.; Bear, C.E. Conformational defects underlie proteasomal degradation of Dent's disease-causing mutants of ClC-5. Biochem. J. 2013, 452, 391-400. [CrossRef] [PubMed]

14. Lourdel, S.; Grand, T.; Burgos, J.; González, W.; Sepúlveda, F.V.; Teulon, J. ClC-5 mutations associated with Dent's disease: A major role of the dimer interface. Pflug. Arch. 2012, 463, 247-256. [CrossRef] [PubMed]

15. Grand, T.; L'Hoste, S.; Mordasini, D.; Defontaine, N.; Keck, M.; Pennaforte, T.; Genete, M.; Laghmani, K.; Teulon, J.; Lourdel, S. Heterogeneity in the processing of CLCN5 mutants related to Dent disease. Hum. Mutat. 2011, 32, 476-483. [CrossRef] [PubMed]

16. Smith, A.J.; Reed, A.A.; Loh, N.Y.; Thakker, R.V.; Lippiat, J.D. Characterization of Dent's disease mutations of CLC-5 reveals a correlation between functional and cell biological consequences and protein structure. Am. J. Physiol. Ren. Physiol. 2009, 296, F390-F397. [CrossRef]

17. Ludwig, M.; Doroszewicz, J.; Seyberth, H.W.; Bökenkamp, A.; Balluch, B.; Nuutinen, M.; Utsch, B.; Waldegger, S. Functional evaluation of Dent's disease-causing mutations: Implications for $\mathrm{ClC}-5$ channel trafficking and internalization. Hum. Genet. 2005, 117, 228-237. [CrossRef]

18. Hoopes, R.R., Jr.; Raja, K.M.; Koich, A.; Hueber, P.; Reid, R.; Knohl, S.J.; Scheinman, S.J. Evidence for genetic heterogeneity in Dent's disease. Kidney Int. 2004, 65, 1615-1620. [CrossRef] 
19. Hoopes, R.R., Jr.; Shrimpton, A.E.; Knohl, S.J.; Hueber, P.; Reed, A.A.; Christie, P.T.; Igarashi, T.; Lee, P.; Lehman, A.; White, C.; et al. Dent disease with mutations in OCRL1. Am. J. Hum. Genet. 2005, 76, 260-267. [CrossRef]

20. Hichri, H.; Rendu, J.; Monnier, N.; Coutton, C.; Dorseuil, O.; Poussou, R.V.; Baujat, G.; Blanchard, A.; Nobili, F.; Ranchin, B.; et al. From Lowe syndrome to Dent disease: Correlations between mutations of the OCRL1 gene and clinical and biochemical phenotypes. Hum. Mutat. 2011, 32, 379-388. [CrossRef]

21. Shrimpton, A.E.; Hoopes, R.R., Jr.; Knohl, S.J.; Hueber, P.; Reed, A.A.; Christie, P.T.; Igarashi, T.; Lee, P.; Lehman, A.; White, C.; et al. OCRL1 mutations in Dent 2 patients suggest a mechanism for phenotypic variability. Nephron Physiol. 2009, 112, 27-36. [CrossRef] [PubMed]

22. Richards, S.; Aziz, N.; Bale, S.; Bick, D.; Das, S.; Gastier-Foster, J.; Grody, W.W.; Hegde, M.; Lyon, E.; Spector, E.; et al. ACMG Laboratory Quality Assurance Committee. Standards and guidelines for the interpretation of sequence variants: A joint consensus recommendation of the American College of Medical Genetics and Genomics and the Association for Molecular Pathology. Genet. Med. 2015, 17, 405-424. [CrossRef] [PubMed]

23. Jentsch, T.J. Chloride channels are different. Nature 2002, 415, 276-277. [CrossRef] [PubMed]

24. Zampieri, G.; Tran, D.V.; Donini, M.; Navarin, N.; Aiolli, F.; Sperduti, A.; Valle, G. Scuba: Scalable kernel-based gene prioritization. BMC Bioinform. 2018, 19, 23. [CrossRef]

25. Merriman, T.R.; Dalbeth, N. The genetic basis of hyperuricaemia and gout. Jt. Bone Spine 2011, 78, 35-40. [CrossRef]

26. Iharada, M.; Miyaji, T.; Fujimoto, T.; Hiasa, M.; Anzai, N.; Omote, H.; Moriyama, Y. Type 1 sodium-dependent phosphate transporter (SLC17A1 Protein) is a Cl(-)-dependent urate exporter. J. Biol. Chem. 2010, 285, 26107-26113. [CrossRef] [PubMed]

27. Chiba, T.; Matsuo, H.; Kawamura, Y.; Nagamori, S.; Nishiyama, T.; Wei, L.; Nakayama, A.; Nakamura, T.; Sakiyama, M.; Takada, T.; et al. NPT1/SLC17A1 is a renal urate exporter in humans and its common gain-of-function variant decreases the risk of renal under-excretion gout. Arthritis Rheumatol. 2015, 67, $281-287$. [CrossRef]

28. Higashino, T.; Matsuo, H.; Sakiyama, M.; Nakayama, A.; Nakamura, T.; Takada, T.; Ogata, H.; Kawamura, Y.; Kawaguchi, M.; Naito, M.; et al. Common variant of PDZ domain containing 1 (PDZK1) gene is associated with gout susceptibility: A replication study and meta-analysis in Japanese population. Drug Metab. Pharm. 2016, 31, 464-466. [CrossRef]

29. Anzai, N.; Kanai, Y.; Endou, H. New insights into renal transport of urate. Curr. Opin. Rheumatol. 2007, 19, 151-157. [CrossRef]

30. De Ligt, J.; Willemsen, M.H.; van Bon, B.W.; Kleefstra, T.; Yntema, H.G.; Kroes, T.; Vulto-van Silfhout, A.T.; Koolen, D.A.; de Vries, P.; Gilissen, C.; et al. Diagnostic exome sequencing in persons with severe intellectual disability. N. Engl. J. Med. 2012, 367, 1921-1929. [CrossRef]

31. Alexander, R.T.; Dimke, H.; Cordat, E. Proximal tubular NHEs: Sodium, protons and calcium? Am. J. Physiol. Ren. Physiol. 2013, 305, F229-F236. [CrossRef] [PubMed]

32. Biemesderfer, D.; Nagy, T.; DeGray, B.; Aronson, P. Specific association of megalin and the Na+/H+ exchanger isoform NHE3 in the proximal tubule. J. Biol. Chem. 1999, 274, 17518-17524. [CrossRef]

33. Gekle, M.; Völker, K.; Mildenberger, S.; Freudinger, R.; Shull, G.E.; Wiemann, M. NHE3 Na+/H+ exchanger supports proximal tubular protein reabsorption in vivo. Am. J. Physiol. Ren. Physiol. 2004, 287, F469-F473. [CrossRef] [PubMed]

34. Szczepanska, M.; Zaniew, M.; Recker, F.; Mizerska-Wasiak, M.; Zaluska-Lesniewska, I.; Kilis-Pstrusinska, K.; Adamczyk, P.; Zawadzki, J.; Pawlaczyk, K.; Ludwig, M.; et al. Dent disease in children: Diagnostic and therapeutic considerations. Clin. Nephrol. 2015, 84, 222-230. [CrossRef] [PubMed]

35. Tang, X.; Brown, M.R.; Cogal, A.G.; Gauvin, D.; Harris, P.C.; Lieske, J.C.; Romero, M.F.; Chang, M.H. Functional and transport analyses of CLCN5 genetic changes identified in Dent disease patients. Physiol. Rep. 2016, 4, e12776. [CrossRef] [PubMed]

36. Li, F.; Yue, Z.; Xu, T.; Chen, M.; Zhong, L.; Liu, T.; Jing, X.; Deng, J.; Hu, B.; Liu, Y.; et al. Dent Disease in Chinese Children and Findings from Heterozygous Mothers: Phenotypic Heterogeneity, Fetal Growth, and 10 Novel Mutations. J. Pediatr. 2016, 174, 204-210.e1. [CrossRef]

37. Kubo, K.; Aizawa, T.; Watanabe, S.; Tsugawa, K.; Tsuruga, K.; Ito, E.; Joh, K.; Tanaka, H. Does Dent disease remain an underrecognized cause for young boys with focal glomerulosclerosis? Pediatr. Int. 2016, 58, 747-749. [CrossRef] 
38. Wong, W.; Poke, G.; Stack, M.; Kara, T.; Prestidge, C.; Flintoff, K. Phenotypic variability of Dent disease in a large New Zealand kindred. Pediatr. Nephrol. 2017, 32, 365-369. [CrossRef]

39. Guven, A.; Al-Rijjal, R.A.; BinEssa, H.A.; Dogan, D.; Kor, Y.; Zou, M.; Kaya, N.; Alenezi, A.F.; Hancili, S.; Tarım, Ö.; et al. Mutational analysis of PHEX, FGF23 and CLCN5 in patients with hypophosphataemic rickets. Clin. Endocrinol. 2017, 87, 103-112. [CrossRef]

40. Günthner, R.; Wagner, M.; Thurm, T.; Ponsel, S.; Höfele, J.; Lange-Sperandio, B. Identification of co-occurrence in a patient with Dent's disease and ADA2-deficiency by exome sequencing. Gene 2018, 649, 23-26. [CrossRef]

41. Sancakli, O.; Kulu, B.; Sakallioglu, O. A novel mutation of Dent's disease in an 11-year-old male with nephrolithiasis and nephrocalcinosis. Arch. Argent. Pediatr. 2018, 116, e442-e444.

42. Bignon, Y.; Alekov, A.; Frachon, N.; Lahuna, O.; Jean-Baptiste Doh-Egueli, C.; Deschênes, G.; Vargas-Poussou, R.; Lourdel, S. A novel CLCN5 pathogenic mutation supports Dent disease with normal endosomal acidification. Hum. Mutat. 2018, 39, 1139-1149. [CrossRef] [PubMed]

43. Wen, M.; Shen, T.; Wang, Y.; Li, Y.; Shi, X.; Dang, X. Next-Generation Sequencing in Early Diagnosis of Dent Disease 1: Two Case Reports. Front. Med. 2018, 5, 347. [CrossRef] [PubMed]

44. Matsumoto, A.; Matsui, I.; Mori, T.; Sakaguchi, Y.; Mizui, M.; Ueda, Y.; Takahashi, A.; Doi, Y.; Shimada, K.; Yamaguchi, S.; et al. Severe Osteomalacia with Dent Disease Caused by a Novel Intronic Mutation of the CLCN5 gene. Intern. Med. 2018, 57, 3603-3610. [CrossRef] [PubMed]

45. Ye, Q.; Shen, Q.; Rao, J.; Zhang, A.; Zheng, B.; Liu, X.; Shen, Y.; Chen, Z.; Wu, Y.; Hou, L.; et al. Multicenter study of the clinical features and mutation gene spectrum of Chinese children with Dent disease. Clin. Genet. 2019. [CrossRef]

46. Wu, F.; Roche, P.; Christie, P.T.; Loh, N.Y.; Reed, A.A.; Esnouf, R.M.; Thakker, R.V. Modeling study of human renal chloride channel (hCLC-5) mutations suggests a structural-functional relationship. Kidney Int. 2003, 63, 1426-1432. [CrossRef]

47. Meyer, S.; Savaresi, S.; Forster, I.C.; Dutzler, R. Nucleotide recognition by the cytoplasmic domain of the human chloride transporter ClC-5. Nat. Struct. Mol. Biol. 2007, 14, 60-67. [CrossRef]

48. Wellhauser, L.; Luna-Chavez, C.; D'Antonio, C.; Tainer, J.; Bear, C.E. ATP induces conformational changes in the carboxylterminal region of ClC-5. J. Biol. Chem. 2011, 286, 6733-6741. [CrossRef]

49. Zifarelli, G.; Pusch, M. Intracellular regulation of human ClC-5 by adenine nucleotides. EMBO Rep. 2009, 10, 1111-1116. [CrossRef]

50. Grand, T.; Mordasini, D.; L'Hoste, S.; Pennaforte, T.; Genete, M.; Biyeyeme, M.J.; Vargas-Poussou, R.; Blanchard, A.; Teulon, J.; Lourdel, S. Novel CLCN5 mutations in patients with Dent's disease result in altered ion currents or impaired exchanger processing. Kidney Int. 2009, 76, 999-1005. [CrossRef]

51. Pusch, M.; Ludewig, U.; Jentsch, T.J. Temperature dependence of fast and slow gating relaxations of CLC-0 chloride channels. J. Gen. Physiol. 1997, 109, 105-116. [CrossRef] [PubMed]

52. Igarashi, T.; Günther, W.; Sekine, T.; Inatomi, J.; Shiraga, H.; Takahashi, S.; Suzuki, J.; Tsuru, N.; Yanagihara, T.; Shimazu, M.; et al. Functional characterization of renal chloride channel, CLCN5, mutations associated with Dent's Japan disease. Kidney Int. 1998, 54, 1850-1856. [CrossRef] [PubMed]

53. Devuyst, O.; Christie, P.T.; Courtoy, P.J.; Beauwens, R.; Thakker, R.V. Intra-renal and subcellular distribution of the human chloride channel, CLC-5, reveals a pathophysiological basis for Dent's disease. Hum. Mol. Genet. 1999, 8, 247-257. [CrossRef] [PubMed]

54. Wang, Y.; Cai, H.; Cebotaru, L.; Hryciw, D.H.; Weinman, E.J.; Donowitz, M.; Guggino, S.E.; Guggino, W.B. ClC-5: Role in endocytosis in the proximal tubule. Am. J. Physiol. Ren. Physiol. 2005, 289, F850-F862. [CrossRef]

55. Hryciw, D.H.; Wang, Y.; Devuyst, O.; Pollock, C.A.; Poronnik, P.; Guggino, W.B. Cofilin interacts with ClC-5 and regulates albumin uptake in proximal tubule cell lines. J. Biol. Chem. 2003, 278, 40169-40176. [CrossRef]

56. Kellermayer, R. Translational readthrough induction of pathogenic nonsense mutations. Eur. J. Med. Genet. 2006, 49, 445-450. [CrossRef]

57. Oren, Y.S.; Pranke, I.M.; Kerem, B.; Sermet-Gaudelus, I. The suppression of premature termination codons and the repair of splicing mutations in CFTR. Curr. Opin. Pharmacol. 2017, 34, 125-131. [CrossRef]

58. Piwon, N.; Günther, W.; Schwake, M.; Bösl, M.R.; Jentsch, T.J. ClC-5 Cl--channel disruption impairs endocytosis in a mouse model for Dent's disease. Nature 2000, 408, 369-373. [CrossRef] 
59. Norden, A.G.; Lapsley, M.; Igarashi, T.; Kelleher, C.L.; Lee, P.J.; Matsuyama, T.; Scheinman, S.J.; Shiraga, H.; Sundin, D.P.; Thakker, R.V.; et al. Urinary megalin deficiency implicates abnormal tubular endocytic function in Fanconi syndrome. J. Am. Soc. Nephrol. 2002, 13, 125-133.

60. Tanuma, A.; Sato, H.; Takeda, T.; Hosojima, M.; Obayashi, H.; Hama, H.; Iino, N.; Hosaka, K.; Kaseda, R.; Imai, N.; et al. Functional characterization of a novel missense CLCN5 mutation causing alterations in proximal tubular endocytic machinery in Dent's disease. Nephron Physiol. 2007, 107, p87-p97. [CrossRef]

61. Santo, Y.; Hirai, H.; Shima, M.; Yamagata, M.; Michigami, T.; Nakajima, S.; Ozono, K. Examination of megalin in renal tubular epithelium from patients with Dent disease. Pediatr. Nephrol. 2004, 19, 612-615. [CrossRef] [PubMed]

62. Gorvin, C.M.; Wilmer, M.J.; Piret, S.E.; Harding, B.; van den Heuvel, L.P.; Wrong, O.; Jat, P.S.; Lippiat, J.D.; Levtchenko, E.N.; Thakker, R.V. Receptor-mediated endocytosis and endosomal acidification is impaired in proximal tubule epithelial cells of Dent disease patients. Proc. Natl. Acad. Sci. USA 2013, 110, 7014-7019. [CrossRef] [PubMed]

63. Anglani, F.; D’Angelo, A.; Bertizzolo, L.M.; Tosetto, E.; Ceol, M.; Cremasco, D.; Bonfante, L.; Addis, M.A.; Del Prete, D. Dent Disease Italian Network. Nephrolithiasis; kidney failure and bone disorders in Dent disease patients with and without CLCN5 mutations. SpringerPlus 2015, 4, 492. [CrossRef]

64. Anglani, F.; Terrin, L.; Brugnara, M.; Battista, M.; Cantaluppi, V.; Ceol, M.; Bertoldi, L.; Valle, G.; Joy, M.P.; Pober, B.R.; et al. Hypercalciuria and nephrolithiasis: Expanding the renal phenotype of Donnai-Barrow syndrome. Clin. Genet. 2018, 94, 187-188. [CrossRef] [PubMed]

65. Köttgen, A.; Albrecht, E.; Teumer, A.; Vitart, V.; Krumsiek, J.; Hundertmark, C.; Pistis, G.; Ruggiero, D.; O'Seaghdha, C.M.; Haller, T.; et al. Genome-wide association analyses identify 18 new loci associated with serum urate concentrations. Nat. Genet. 2013, 45, 145-154. [CrossRef] [PubMed]

66. Phipps-Green, A.J.; Merriman, M.E.; Topless, R.; Altaf, S.; Montgomery, G.W.; Franklin, C.; Jones, G.T.; van Rij, A.M.; White, D.; Stamp, L.K.; et al. Twenty-eight loci that influence serum urate levels: Analysis of association with gout. Ann. Rheum. Dis. 2016, 75, 124-130. [CrossRef] [PubMed]

67. Ketharnathan, S.; Leask, M.; Boocock, J.; Phipps-Green, A.J.; Antony, J.; O'Sullivan, J.M.; Merriman, T.R.; Horsfield, J.A. A non-coding genetic variant maximally associated with serum urate levels is functionally linked to HNF4A-dependent PDZK1 expression. Hum. Mol. Genet. 2018, 27, 3964-3973. [CrossRef]

68. Gisler, S.M.; Pribanic, S.; Bacic, D.; Forrer, P.; Gantenbein, A.; Sabourin, L.A.; Tsuji, A.; Zhao, Z.S.; Manser, E.; Biber, J.; et al. PDZK1: I. a major scaffolder in brush borders of proximal tubular cells. Kidney Int. 2003, 64, 1733-1745. [CrossRef]

69. Capuano, P.; Bacic, D.; Stange, G.; Hernando, N.; Kaissling, B.; Pal, R.; Kocher, O.; Biber, J.; Wagner, C.A.; Murer, H. Expression and regulation of the renal Na/phosphate cotransporter NaPi-IIa in a mouse model deficient for the PDZ protein PDZK1. Pflug. Arch. 2005, 449, 392-402. [CrossRef]

70. Slattery, C.; Jenkin, K.A.; Lee, A.; Simcocks, A.C.; McAinch, A.J.; Poronnik, P.; Hryciw, D.H. Na+-H+ exchanger regulatory factor 1 (NHERF1) PDZ scaffold binds an internal binding site in the scavenger receptor megalin. Cell. Physiol. Biochem. 2011, 27, 171-178. [CrossRef]

71. Sakiyama, M.; Matsuo, H.; Nagamori, S.; Ling, W.; Kawamura, Y.; Nakayama, A.; Higashino, T.; Chiba, T.; Ichida, K.; Kanai, Y.; et al. Expression of a human NPT1/SLC17A1 missense variant which increases urate export. Nucleosides Nucleotides Nucleic Acids 2016, 35, 536-542. [CrossRef] [PubMed]

72. Böger, C.A.; Chen, M.H.; Tin, A.; Olden, M.; Köttgen, A.; de Boer, I.H.; Fuchsberger, C.; O'Seaghdha, C.M.; Pattaro, C.; Teumer, A.; et al. CUBN is a gene locus for albuminuria. J. Am. Soc. Nephrol. 2011, 22, 555-570. [CrossRef] [PubMed]

73. Ovunc, B.; Otto, E.A.; Vega-Warner, V.; Saisawat, P.; Ashraf, S.; Ramaswami, G.; Fathy, H.M.; Schoeb, D.; Chernin, G.; Lyons, R.H.; et al. Exome sequencing reveals cubilin mutation as a single-gene cause of proteinuria. J. Am. Soc. Nephrol. 2011, 22, 1815-1820. [CrossRef] [PubMed]

74. Tanner, S.M.; Sturm, A.C.; Baack, E.C.; Liyanarachchi, S.; de la Chapelle, A. Inherited cobalamin malabsorption. Mutations in three genes reveal functional and ethnic patterns. Orphanet J. Rare Dis. 2012, 7, 56. [CrossRef] [PubMed]

75. Schäffer, A.A. Digenic inheritance in medical genetics. J. Med. Genet. 2013, 50, 641-652. [CrossRef] [PubMed]

76. Deltas, C. Digenic inheritance and genetic modifiers. Clin. Genet. 2018, 93, 429-438. [CrossRef] 
77. Janecke, A.R.; Heinz-Erian, P.; Yin, J.; Petersen, B.S.; Franke, A.; Lechner, S.; Fuchs, I.; Melancon, S.; Uhlig, H.H.; Travis, S.; et al. Reduced sodium/proton exchanger NHE3 activity causes congenital sodium diarrhea. Hum. Mol. Genet. 2015, 24, 6614-6623. [CrossRef]

78. Lin, Z.; Jin, S.; Duan, X.; Wang, T.; Martini, S.; Hulamm, P.; Cha, B.; Hubbard, A.; Donowitz, M.; Guggino, S.E. Chloride channel (Clc) -5 is necessary for exocytic trafficking of $\mathrm{Na}+\mathrm{H}+$ exchanger 3 (NHE3). J. Biol. Chem. 2011, 286, 22833-22845. [CrossRef]

79. Pan, W.; Borovac, J.; Spicer, Z.; Hoenderop, J.G.; Bindels, R.J.; Shull, G.E.; Doschak, M.R.; Cordat, E.; Alexander, R.T. The epithelial sodium/proton exchanger; NHE3; is necessary for renal and intestinal calcium (re)absorption. Am. J. Physiol. Ren. Physiol. 2012, 302, F943-F956. [CrossRef]

80. Katsanis, N. The continuum of causality in human genetic disorders. Genome Biol. 2016, 17, 233. [CrossRef]

81. Cooper, D.N.; Krawczak, M.; Polychronakos, C.; Tyler-Smith, C.; Kehrer-Sawatzki, H. Where genotype is not predictive of phenotype: Towards an understanding of the molecular basis of reduced penetrance in human inherited disease. Hum. Genet. 2013, 132, 1077-1130. [CrossRef] [PubMed]

82. Tosetto, E.; Ghiggeri, G.M.; Emma, F.; Barbano, G.; Carrea, A.; Vezzoli, G.; Torregrossa, R.; Cara, M.; Ripanti, G.; Ammenti, A.; et al. Phenotypic and genetic heterogeneity in Dent's disease: The results of an Italian collaborative study. Nephrol. Dial. Transplant. 2006, 21, 2452-2463. [CrossRef] [PubMed]

83. Van Berkel, Y.; Ludwig, M.; van Wijk, J.A.E.; Bökenkamp, A. Proteinuria in Dent disease: A review of the literature. Pediatr. Nephrol. 2017, 32, 1851-1859. [CrossRef]

84. Schwarz, J.M.; Cooper, D.N.; Schuelke, M.; Seelow, D. MutationTaster2: Mutation prediction for the deep-sequencing age. Nat. Methods 2014, 11,361-362. [CrossRef] [PubMed]

85. Bertoldi, L.; Forcato, C.; Vitulo, N.; Birolo, G.; De Pascale, F.; Feltrin, E.; Schiavon, R.; Anglani, F.; Negrisolo, S.; Zanetti, A.; et al. QueryOR: A comprehensive web platform for genetic variant analysis and prioritization. BMC Bioinform. 2017, 18, 225. [CrossRef] [PubMed]

86. Kumar, P.; Henikoff, S.; Ng, P.C. Predicting the effects of coding non-synonymous variants on protein function using the SIFT algorithm. Nat. Protoc. 2009, 4, 1073-1081. [CrossRef] [PubMed]

87. Adzhubei, I.; Jordan, D.M.; Sunyaev, S.R. Predicting functional effect of human missense mutations using PolyPhen-2. Curr. Protoc. Hum. Genet. 2013, 7, 7.20.1-7.20.41. [CrossRef]

88. Yongwook, C.; Agnes, P.C. PROVEAN web server: A tool to predict the functional effect of amino acid substitutions and indels. Bioinformatics 2015, 31, 2745-2747.

89. Kircher, M.; Witten, D.M.; Jain, P.; O’Roak, B.J.; Cooper, G.M.; Shendure, J. A general framework for estimating the relative pathogenicity of human genetic variants. Nat. Genet. 2014, 46, 310-315. [CrossRef]

90. Quang, D.; Chen, Y.; Xie, X. DANN: A deep learning approach for annotating the pathogenicity of genetic variants. Bioinformatics 2015, 31, 761-763. [CrossRef]

91. Ceol, M.; Tiralongo, E.; Baelde, H.J.; Vianello, D.; Betto, G.; Marangelli, A.; Bonfante, L.; Valente, M.; Della Barbera, M.; D'Angelo, A.; et al. Involvement of the tubular ClC-type exchanger ClC-5 in glomeruli of human proteinuric nephropathies. PLoS ONE 2012, 7, e45605. [CrossRef] [PubMed]

92. Gianesello, L.; Priante, G.; Ceol, M.; Radu, C.M.; Saleem, M.A.; Simioni, P.; Terrin, L.; Anglani, F.; Del Prete, D. Albumin uptake in human podocytes: A possible role for the cubilin-amnionless (CUBAM) complex. Sci. Rep. 2017, 7, 13705. [CrossRef] [PubMed]

93. R Development Core Team. R: A Language and Environment for Statistical Computing; R Foundation for Statistical Computing: Vienna, Austria, 2008; ISBN 3-900051-07-0.

(C) 2020 by the authors. Licensee MDPI, Basel, Switzerland. This article is an open access article distributed under the terms and conditions of the Creative Commons Attribution (CC BY) license (http://creativecommons.org/licenses/by/4.0/). 